\title{
Clinicopathological profile of paediatric vitellointestinal duct anomalies
}

\author{
Othuluru Hema Radhika Krishna1, Srinivas Srirampur², Gaddam Janardhan Vani Padmaja ${ }^{3}$, \\ Ramesh Reddy Kota ${ }^{4}$
}

${ }^{1}$ Associate Professor, Department of Pathology, Osmania Medical College, Hyderabad, Telangana, India, ${ }^{2}$ Associate Professor, Department of Pediatric Surgery, Gandhi Medical College, Hyderabad, Telangana, India, ${ }^{3}$ Professor, Department of Pathology, Niloufer Hospital, Osmania Medical College, Hyderabad, Telangana, India, ${ }^{4}$ Professor, Department of Pediatric Surgery, Niloufer Institute of Pediatrics, Hyderabad, Telangana, India

Background: Vitellointestinal duct (VID) or Omphalomesenteric duct (OMD) is the embryonic connection between the yolk sac and the primitive midgut. Anomalies result from failure of the involution of the VID. Normally, it obliterates between the fifth and seventh weeks of fetal life. They include Meckel's diverticulum (MD), fibrous band, fistula, sinus tract, cyst, and umbilical polyp. Symptomatic cases require surgical correction. They are characterised by different clinical presentations and histological appearances. This study gathers a single paediatric institutional experience of VID remnants, their demographic, clinical profile, varied histomorphology including the presence of ectopic tissues. Aims and Objectives: The objective of this study was to retrospectively review all the symptomatic cases of VID abnormalities at a tertiary pediatric referral hospital. The demographic profile, clinical presentation, and histopathology were reviewed and descriptively analyzed. We classified these anomalies based on embryology and histology. The findings of this study will provide insights to pathologists and treating clinicians less exposed to these rare lesions. Materials and Methods: Data was retrieved retrospectively from the pathology records of a tertiary paediatric referral institute for 3 years. Histological slides of VID anomalies were reviewed and a descriptive analysis of the findings was performed. A thorough review of the literature was also done on these very rare lesions and their findings compared to our results. Results: A total of 60 cases of VID anomalies were encountered during the study period. There was significant male preponderance. The most common age group at surgery was infancy. MD was the commonest VID anomaly. The least common was vitelline fistula and only a single case was encountered in the study period. Ectopic tissues were seen in $25 \%$ of the cases and included gastric and colonic mucosae and pancreatic tissue. Conclusion: The histopathology of VID anomalies provides an interesting diagnostic experience for the reporting pathologist. Awareness of the embryology, presentation and histology of these lesions aids in accurate diagnosis.

Key words: Paediatric Vitellointestinal duct anomaly; Histology; Ectopic tissue
Access this article online

Website:

http://nepjol.info/index.php/AJMS DOI: 10.3126/ajms.v12i10.38233

E-ISSN: 2091-0576

P-ISSN: 2467-9100

Copyright (c) 2021 Asian Journal of Medical Sciences

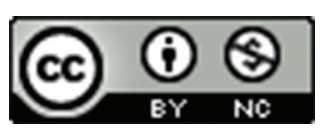

This work is licensed under a Creative Commons Attribution-NonCommercial 4.0 International License.

\section{INTRODUCTION}

The umbilicus is similar to the neck of a bottle which carries the umbilical vessels and the structures of the digestive and urinary tract during the intrauterine life. ${ }^{1} \mathrm{It}$ is an important embryonic and anatomic landmark on the anterior abdominal wall. Most of the umbilical disorders are congenital. ${ }^{2}$ Development of the umbilicus begins around the fourth week of fetal life, when the folding of the embryonic disk results in the division of the yolk sac into two parts, an intraceolomic and an extraceolomic part called definitive yolk sac. These two are connected by the vitellointestinal duct (VID) or omphalomesenteric duct (OMD). ${ }^{3}$ The umbilical cord has two tubular structures. One is the VID and the second is allantois that extends from the cloaca as a blind pouch within the umbilical cord. During normal development, the VID disappears around 5-9 weeks of intrauterine life and the allantois is reduced to a fibrous cord called urachus between 8-16 weeks of life. Around the time of birth, the VID and the yolk sac

\section{Address for Correspondence:}

Dr. O. H. Radhika Krishna, Associate Professor, Department of Pathology, Osmania Medical College, Hyderabad, Telangana, India. Mobile No: +91-9866283836. E-mail: othulururadhika@yahoo.co.in 
disappear completely leaving only two umbilical arteries and one umbilical vein. This process of obliteration begins on the umbilical end and extends towards the intestine. The failure of VID to disappear at birth results in vitello intestinal duct anomalies.

Vitelline duct pathology results in a spectrum of anomalies like Meckel's diverticulum (MD), vitelline cyst or OMD cyst, persistent fibrous cord, umbilical sinus or vitelline sinus, and persistent vitellointestinal duct (PVID) or VID fistula discharging contents of small bowel. ${ }^{4}$ Remnants of VID are reported to be present in 2-4\% of post mortem examinations. ${ }^{5}$ Symptomatic cases need surgical intervention. A large majority of cases however go unrecognized. ${ }^{6}$

\section{Aims and objectives}

The objective of this study was to retrospectively review all the symptomatic cases of VID abnormalities at a tertiary pediatric referral hospital. The demographic profile, clinical presentation, and histopathology were reviewed and descriptively analyzed. We classified these anomalies based on embryology and histology. The findings of this study will provide insights to pathologists and treating clinicians less exposed to these rare lesions.

\section{MATERIALS AND METHODS}

A retrospective descriptive study of VID remnants of 3 years' duration was taken up at a tertiary pediatric referral hospital. Pathology records of the surgical specimens of cutaneous VID remnants and Meckel's diverticulum received were analyzed from June 2015 to June 2018. The available patient related information, gender, age at surgery, the clinical presentation was retrieved along with gross and microscopic findings. A detailed histopathological analysis of the hematoxylin and eosin stained slides of all the cases was performed by two pathologists. The epithelial lining of the VID remnants along with presence of any ectopic or heterotopic tissue was studied.

A descriptive analysis of the findings was performed and results interpreted. The age and sex distribution of all the cases of VID anomalies along with number and percentage of each anomaly was derived. The number of cases showing different clinical features and the percentage of cases with ectopic mucosal tissues and type of the ectopic lining epithelium has been described in every anomaly of VID.

All cases of VID remnants during the study period were included. Persistent urachus, other urachal anomalies, and umbilical granulomas were excluded from the study.

\section{RESULTS}

Sixty cases of VID remnants were retrieved from the pathology records during the study period, and a total of six different types of anomalies of VID were encountered. The detailed division of the VID remnants, along with the age at presentation, sex predilection, clinical presentation, and histology is described in Table 1.

Male to female incidence was 1.8: 1 and most of the cases $21(35 \%)$ were less than a year old. Meckel's diverticulum was the commonest anomaly accounting for nearly $75 \%$ of the cases. Vitelline sinus was the least common (Table 1). The findings of each entity in the spectrum of VID remnants will be discussed separately.

Meckel's diverticulum was seen in 45 cases. There was a male preponderance at the ratio of 2.2:1. Age incidence was as follows, $0-1$ years -17 cases, $1-2$ years- 10 cases, $2-5$ years -7 cases, and $5-10$ years -11 cases. Most of the patients were infants $(37.77 \%)$. Twenty five patients presented with intestinal obstruction. Ten $(22.2 \%)$ presented with diverticulitis and $4(8.88 \%)$ presented with lower gastrointestinal bleeding.

On microscopy, transmural inflammation was seen in 33 cases $(73.3 \%)$. Ten cases $(22.2 \%)$ showed submucosal lymphoid hyperplasia. Small intestinal lining along with heterotopic pancreas was seen in 6 cases $(13.33 \%$ ) and small intestinal lining with heterotopic gastric mucosa in 4 cases $(8.88 \%)$. Only ectopic pancreatic tissue was seen in 2 cases (4.44\%) of MD (Image 1).

Vitelline band or fibrous remnant of VID was seen in 6 cases $(10 \%)$. Four were male and 2 female children. Age distribution in this second common lesion in the study was

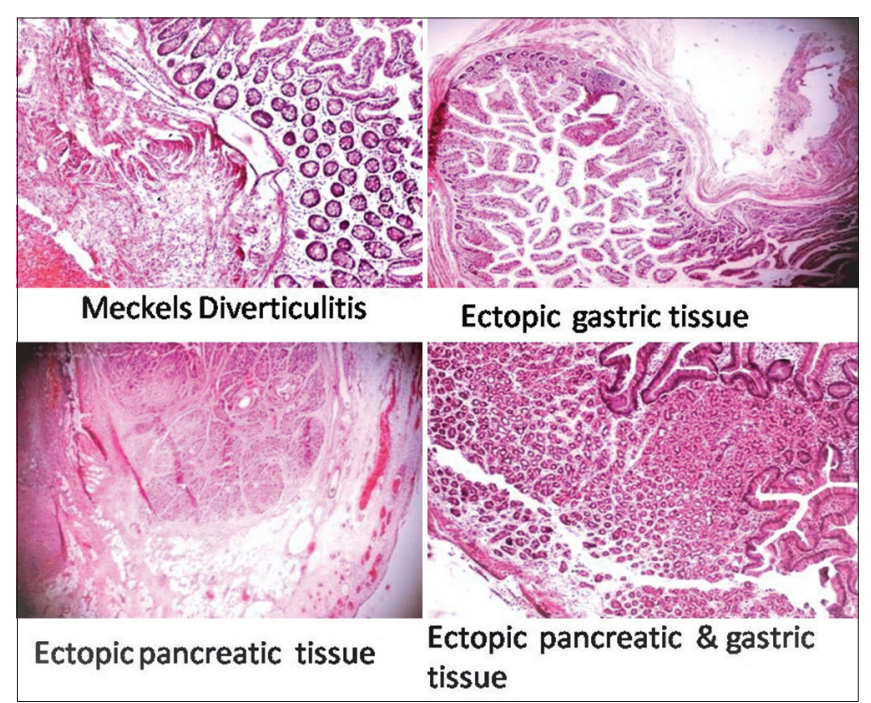

Image 1: H\&E stain x40, Microscopic images of Meckel's diverticulum showing ectopic gastric and pancreatic tissues 


\begin{tabular}{|c|c|c|c|c|c|c|}
\hline S.No & $\begin{array}{l}\text { VID } \\
\text { Anomaly }\end{array}$ & $\begin{array}{l}\text { No of cases }(\%) \\
N=60\end{array}$ & $\begin{array}{l}\text { Age at } \\
\text { presentation(\%) }\end{array}$ & $\begin{array}{l}\text { Sex } \\
\text { incidence }\end{array}$ & $\begin{array}{l}\text { Clinical } \\
\text { presentation(\%) }\end{array}$ & Histology/ ectopic tissue \\
\hline 1 & $\begin{array}{l}\text { Meckel's } \\
\text { diverticulum }\end{array}$ & $45(75)$ & $\begin{array}{l}0-1 \text { years- } 17 \\
(37.77) \\
1-2 \\
\text { years-10(22.22) } \\
2-5 \text { years- } \\
7(15.55) \\
5-10 \text { years- } \\
11(24.44)\end{array}$ & $1.8: 1$ & $\begin{array}{l}\text { Intestinal } \\
\text { obstruction-25(55.55) } \\
\text { Diverticulitis-10 } \\
(22.22) \\
\text { Lower GI } \\
\text { bleed-4(8.88) }\end{array}$ & $\begin{array}{l}\text { Small intestinal lining along with } \\
\text { heterotopic pancreas seen in } 6 \\
\text { cases }(13.33 \%) \\
\text { Small intestinal lining with } \\
\text { heterotopic gastric mucosa seen } \\
\text { in } 4 \text { cases }(8.88 \%) \\
\text { Only ectopic pancreatic tissue } \\
\text { was seen in } 2 \text { cases }(4.44 \%)\end{array}$ \\
\hline 2 & $\begin{array}{l}\text { Vitelline } \\
\text { band }\end{array}$ & $6(10)$ & $\begin{array}{l}\text { years-1(16.66) } \\
2-5 \\
\text { years-1(16.66) } \\
5-10 \\
\text { years-4(66.66) }\end{array}$ & $2: 1$ & $\begin{array}{l}\text { Intestinal obstruction } \\
-4(66.66) \\
\text { Pain abdomen }-2 \\
(33.33)\end{array}$ & $\begin{array}{l}\text { Fibro collagenous band seen in } \\
6 \text { cases }(100) \\
\text { Ectopic tissue- none }\end{array}$ \\
\hline 3 & PVID & $4(6.6)$ & $\begin{array}{l}\text { Age less than } \\
\text { one month - } \\
4(100)\end{array}$ & $3: 1$ & $\begin{array}{l}\text { Umbilical } \\
\text { swelling-3(75) } \\
\text { Umbilical } \\
\text { discharge-3(75) } \\
\text { Omphalocele } \\
\text { minor-1(25) }\end{array}$ & $\begin{array}{l}\text { Small intestinal epithelium seen } \\
\text { in } 4 \text { cases }(100) \\
\text { Ectopic tissue- none }\end{array}$ \\
\hline 4 & OMD Cyst & $2(3.3)$ & $\begin{array}{l}<\text { one month }-1 \\
7 \text { months }-1\end{array}$ & Both female & $\begin{array}{l}\text { Umbilical discharge } \\
-2(100)\end{array}$ & $\begin{array}{l}\text { Cyst wall with Small intestinal } \\
\text { epithelium-1(50) } \\
\text { Pancreatic tissue seen in } 1(50)\end{array}$ \\
\hline 5 & $\begin{array}{l}\text { Umbilical } \\
\text { polyp }\end{array}$ & $2(3.3)$ & $\begin{array}{l}11 \text { months-1 } \\
3 \text { years-1 }\end{array}$ & Both female & $\begin{array}{l}\text { Umbilical swelling } \\
\text { and discharge - } \\
2(100)\end{array}$ & $\begin{array}{l}\text { Small intestinal epithelium seen } \\
\text { in } 1(50) \\
\text { Colonic epitheliumseen in } 1(50)\end{array}$ \\
\hline 6 & $\begin{array}{l}\text { Umbilical } \\
\text { sinus }\end{array}$ & $1(1.6)$ & $31 / 2$ years & Male & $\begin{array}{l}\text { Umbilical discharge } \\
1(100)\end{array}$ & $\begin{array}{l}\text { Colonic epithelium seen in } \\
1(100)\end{array}$ \\
\hline
\end{tabular}

0-1 year- 1 case, 2-5 years- 1 case, and 5-10 years- 4 cases. The highest incidence was in older children i.e. 5-10 years $66.6 \%$. Four cases presented as intestinal obstruction and 2 as pain abdomen. Histopathology revealed linear band of fibro collagenous tissue devoid of lining epithelium (Image 2).

Persistent VID or VID fistula was seen in 4 cases. 3 cases (75\%) presented with small growth at the umbilicus and umbilical discharge of fecal matter and one case had associated omphalocele minor. All cases presented in the neonatal age group. Microscopy revealed small intestinal mucosa No ectopic tissues were noted in these cases (Image 2).

We encountered 2 cases of OMD cyst or vitelline cyst. One of the cases was a neonate and another was a 7-month old child. Both cases were females and both presented with umbilical discharge. On histological examination, in one of the cases the cyst wall was lined by small intestinal mucosa and in the other case by pancreatic tissue (Image 3).

We received 2 cases of umbilical polyp in the study period. Both were males one case was 11 month old child who presented with umbilical swelling and foul smelling discharge, the other child was 3 years old and presented with umbilical swelling and a history of bleeding on trauma. Histology in one of the cases was characterized by the presence of small intestinal epithelium and in the younger

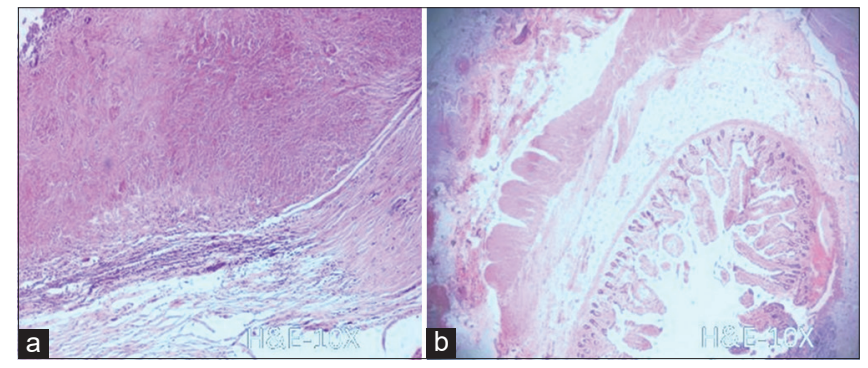

Image 2: (a) H\&E stain x40, Microscopy of remnant fibrous band showing band of fibro collagenous tissue devoid of lining epithelium and (b) PVID lined by small bowel mucosa

child, a surprising finding of colonic epithelium was seen on microscopy (Image 3).

The last type of anomaly, vitelline or umbilical sinus was present in a $31 / 2$-year old male child with a history of umbilical discharge of 4 months' duration. Histopathology revealed partly a preserved epidermis along with an ulcerated area beneath the epithelium. Underneath the ulcerated surface was colonic mucosa with mucin secreting glands (Image 4).

\section{DISCUSSION}

The umbilicus is considered a mirror of the abdomen ${ }^{1}$ and the umbilical cord is the lifeline between the fetus and 


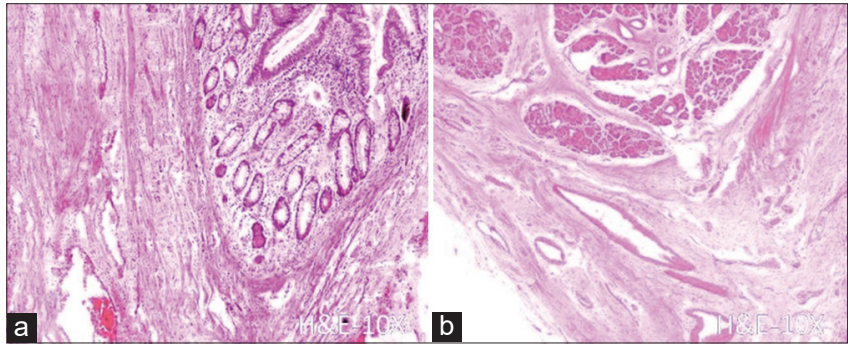

Image 3: (a) H\&E stain $x 40$, Microscopy of umbilical polyp with colonic mucosa and (b) OMD cyst showing ectopic pancreatic tissue

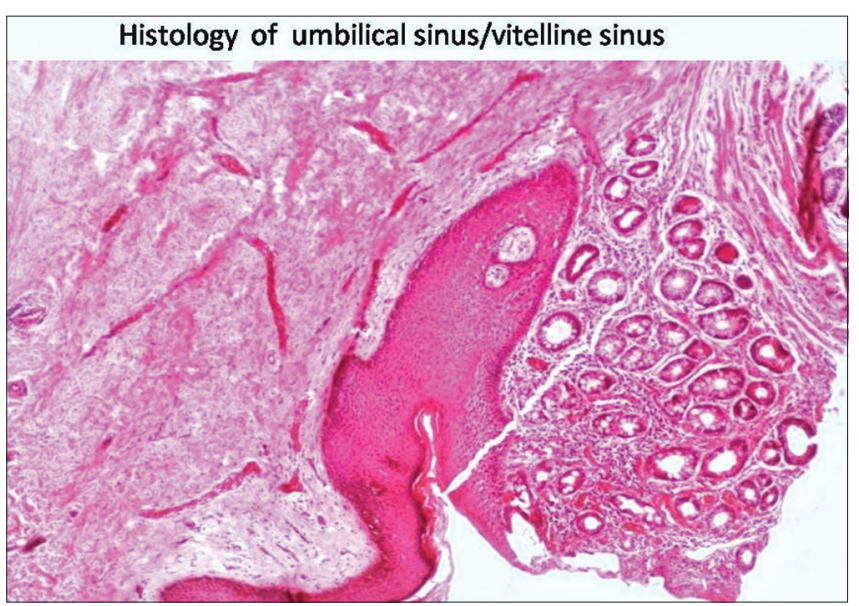

Image 4: H\&E stain $\times 10$, Microscopy of the case of umbilical sinus showing discontinuous stratified squamous epithelium with colonic mucosa

the placenta. The embryo is attached to the placenta by a connecting stalk by the end of the third week of gestation. By 25 days of life yolk sac forms, and around 28 days at the level of the anterior wall of the embryo vitelline duct is formed from the yolk sac. Towards the end of the fifth week of gestation primitive umbilical ring is formed. Surrounding the vitelline duct it contains a) stalk through which the allantois passes along with the paired umbilical arteries and umbilical vein. b) vitelline duct (yolk sac stalk) and c) a canal that connects the intra and extra embryonic coelomic cavities. ${ }^{7}$

The primitive yolk sac divides into two portions intracoelomic and extracoelomic. They are connected by the vitellointestinal duct. Thus VID is an embryonic connection between the extra embryonic yolk sac and the primitive mid gut through the umbilical coelome, and also contains vessels that provide nutrition to the developing embryo till the placenta is formed. ${ }^{8}$ The intracoelomic part develops into midgut and hindgut. At this time a broad communication is present between the developing gut and extracoelomic yolk sac. Differential growth of the anterior body walls and the elongation of the intestinal tract to form the vitelline duct this communication gets narrowed. These structures together with the vitelline artery and vein form the yolk stalk. The umbilical vein, two umbilical arteries and allantois form the body stalk. The diverticulum from the hindgut part of the intraceolomic yolk sac fuses with the yolk stalk and forms the umbilical cord with an allantoic membrane investment. 'The umbilical arteries and veins close after birth forming lateral umbilical ligaments and ligamentum teres respectively.

Around the sixth week of gestation, midgut herniates into the umbilical cord and rotates $90^{\circ}$ counter clockwise around the superior mesenteric artery axis. During the process, VID closes its lumen to become a thin fibrous band which later is obliterated. Incompletely resorbed VID persists and presents as a spectrum of anomalies. Complete patency of the tract is called persistent vitellointestinal duct fistula (PVID), and partial patency of the proximal remnant is called a sinus. A remnant at the umbilicus with no connection to the gut results in aberrant tissue called umbilical polyp or closed OMD. A remnant located at the ileal end with no connection to the umbilicus is a Meckel's diverticulum. An OMD or VID cyst is created when both ends i.e. umbilical and ileal are closed and the mid part of the duct remains patent. A fibrous cord or band develops when only fibrous tissue connects the ileum and umbilicus. ${ }^{10,11}$

This retrospective study was taken up at Niloufer hospital, a tertiary paediatric referral hospital in Hyderabad, India. This hospital caters not only to the state of Telangana, but also to the neighboring states and is a high volume centre for paediatric surgery in south India.

This is the reason for higher incidence of these very cases of these rare lesions in our study. The data that we retrospectively retrieved included 60 cases of VID remnants. The commonest age at presentation and surgery was less than one year $(35 \%)$. There was a significant male preponderance. The cause for this predilection is currently obscure. A similar demographic profile was also noted by other studies., ${ }^{411,12}$

Among the VID anomalies, Meckel's diverticulum was the commonest accounting for $75 \%$ of the cases in our study. A similar study reported $67 \%$ of their symptomatic VID remnant cases to be Meckel's diverticulum. ${ }^{8}$ Meckel's diverticulum is the most common congenital anomaly of the gastrointestinal tract and is present in $2.9 \%$ of the population. ${ }^{13}$ Least common were OMD cyst and umbilical polyp 2 cases each and a single case of vitelline sinus. A retrospective study on 132 neonates with VID remnant pathology found only a single case of OMD sinus. ${ }^{14}$ The authors concluded that sinus was the least common abnormality of VID.

The commonest clinical presentation was intestinal obstruction and umbilical discharge was another common presentation among the cutaneous VID remnants. Similar 
findings were reported by a study titled "Symptomatic OMD remnants in children" 11 and another titled "Cutaneous presentation of OMD remnants." 15

Meckel's diverticulum was described by Fabricus Hiladanus in 1590. It is named after Johann Friedrich Meckel who explained its anatomy and embryologic origin in $1809 .{ }^{16} \mathrm{~A}$ Meckel diverticulum is a true diverticulum, has all the layers of the gut wall, arises from the antimesenteric border of the ileum, and has its own blood supply It remains silent but may present with life alarming complications such as intestinal obstruction, perforation, hemorrhage, and peptic ulceration. The blood supply of MD is from the vitelline artery, a branch of the superior mesenteric artery. Own blood supply makes MD prone to infection and obstruction like the appendix. On imaging, normal Meckel's diverticulum is seen as a blind ending tubular structure arising from the small bowel in the right lower abdomen. Detection on Computed tomography with oral contrast is poor as $\mathrm{MD}$ is seen as a blind ending pouch from the anti-mesenteric border of the ileum resembling the usual small bowel loops. ${ }^{17}$

A microscopic review of the cases of Meckel's diverticulum revealed transmural inflammation $(73.3 \%)$ and lymphoid hyperplasia $(22.2 \%)$. The lining epithelium was predominantly the small intestinal type. Ectopic and heterotopic tissues were seen in 12 cases $(26.6 \%)$. Pancreatic tissue was seen in 8 cases among which 2 cases had only pancreatic tissue and the remaining six cases had ileal mucosal lining along with pancreatic tissue. Four cases showed gastric epithelium along with small intestinal epithelium. A study of symptomatic VID remnants had 259 cases of Meckel's diverticulum and inflammatory changes were present in $49 \%$ and ectopic tissue in $31 \%$ of the cases. These variations may be explained by their large sample size in comparison to our study.

Ectopic gastrointestinal tissue is defined as the presence of gastrointestinal tissue at any part of the gastrointestinal tract other than at its normal anatomical location. Ectopic tissue of gastrointestinal origin is frequently reported in VID remnants, other parts of the gastrointestinal tract like the duodenum and also in extraintestinal sites. ${ }^{18}$

In our series, in addition to Meckel's diverticulum ectopic pancreatic tissue was seen in one among two cases of OMD cyst and a rare finding of the colonic mucosa was noted in one among the 2 cases of umbilical polyp and the isolated case of vitelline sinus. One case of OMD cyst also showed ectopic pancreatic tissue. The overall incidence of ectopic tissue in this study is $25 \%, 15$ out of 60 cases. This is lower in comparison to a similar study which had ectopic tissue in 30 out of 71 cases. $^{19}$

In a study of symptomatic paediatric patients with Meckel's diverticulum, 59\% were found to have ectopic tissue suggesting that the presence of ectopic tissue is proportional to symptomatology in MD. ${ }^{11}$ Presence of ectopic tissues is the major risk factor for acute hemorrhagic or inflammatory complications in $\mathrm{MD} .{ }^{20}$ Brisk hemorrhage presenting as bright red blood in the stool can be seen. Pertechnetate scintigraphy is the investigation of choice in the evaluation of pediatric patients with suspected bleeding from a Meckel diverticulum. Tc99m- pertechnetate accumulates in the parietal mucus-secreting cells of the ectopic gastric mucosa, resulting in focal uptake in the right lower quadrant, which parallels uptake in the stomach. Intestinal obstruction due to a Meckel's diverticulum can occur secondary to twisting of the small bowel around a remnant band, internal hernia called littre hernia occurs from entrapment of an intestinal loop within a mesenteric fold to the diverticulum and intussusception can occur with the diverticulum acting as a lead point.

Umbilical polyps are usually firm, reddish nodules found in the depth of the umbilicus which can be mistaken for granulomas. An ultrasound and fistulogram will determine if a communication exists with the small bowel. They are cutaneous remnants of incomplete obliteration of the OMD. They usually contain small intestinal mucosa, sometimes in association with the gastric mucosa. The study includes a case of an umbilical polyp with colonic mucosa. Few other studies have also found colonic epithelium in a polyp. ${ }^{21}$ In a study out of 13 umbilical polyps, 11 showed small intestinal tissue and one with gastric mucosa, and two showed colonic mucosa. ${ }^{22}$

umbilical sinuses are rare and need exploratory laprotomy with excision of whole tract of the sinus. We encountered only a single case report with colonic mucosa in an umbilical sinus similar to ours on review of the literature. Park reported a case of ectopic pancreas in OMD cyst similar to our study. ${ }^{23}$ Cases of OMD fistulas or PVID with ectopic tissues have been described in the literature. We did not encounter ectopic tissues among the PVID cases in this study. Henirich system is used to classify the ectopic pancreas. ${ }^{24}$ Metaplasia, misplacement, and totipotent theories are proposed to explain pancreatic ectopia. ${ }^{23}$ The misplacement theory proposes, that the embryonic tissue is located in an inappropriate place and develops into mature pancreatic tissue. ${ }^{24}$ Metaplasia theory, states that endodermal tissues migrate to the submucosa during embryogenesis and transform into pancreatic tissue ${ }^{25}$ and the totipotent cell theory, proposes that the totipotent endodermal cells lining the gut or VID differentiate into pancreatic tissue. ${ }^{26,27}$ According to the misplacement theory during rotation of the foregut, many elements of the primitive pancreas become separated and ultimately form mature pancreatic tissue along the length of the gastrointestinal tract. Due to this the heterotopic rests are prone to drop 
off from the dorsal primordium and develop in various locations like the distal part of the stomach and proximal part of the duodenum, which are the most common sites of heterotopic pancreas. This theory cannot explain other rarely discovered locations of the heterotopic pancreas such as Meckel's diverticulum, ampulla of Vater, gallbladder, umbilicus, fallopian tube, and mediastinum. The totipotent cell theory is an acceptable explanation for heterotopic pancreas in the VD remnant because the cells lining the VD are known to be pluripotent and can express either gastric, pancreatic, hepatic, or other terminal endodermderived phenotypes. Normal tissues have a restricted ability to differentiate into other cell types, these tissues appear to escape this restriction and remain pleuripotent.

Ectopic gastric tissue is a common finding and may be a congenitally displaced tissue or a choristoma. It may be a result of irregular distribution of the totipotent cells. The presence of gastric mucosa within them makes VID remnants symptomatic. ${ }^{28}$

Ectopic gastric mucosa can be found anywhere in the gastrointestinal tract including Meckel's diverticulum, the Gall bladder, Cystic duct, the VID, and the liver. ${ }^{29}$ An interesting case report discusses the case of OMD fistula with ectopic gastric mucosa in a six-month old female leading to acidic discharge, inflammation, and ulceration. ${ }^{30}$ We encountered ectopic gastric mucosa in only MD cases in this study. A rare case report of ectopic pancreatic, gastric, and small intestine tissue in a single umbilical polyp has also been described in the literature. ${ }^{31}$

Cullen mentions that "Vestige of heterotopic tissue is a convergence of retarded retrogression of vitello intestinal duct". 32 Heterotopic tissue is more common in VID lesions of children than adults. ${ }^{23}$ Historical mortality reported in VID remnants is $10.3 \%$, it is much less today considering the advances in medical imaging and management. Morbidity is still a major concern due to possible bowel necrosis, evisceration, and hemorrhage. We in this study histologically recognized ectopic tissues in MD, OMD cyst, umbilical polyp, and sinus. vitelline band or persistant VID did not show any ectopic mucosal lining.

VID abnormalities may be associated with umbilical hernias, intestinal atresias, cardiac malformations, cleft lip, palate, and examphalos. ${ }^{33}$ They may also be associated with trisomy 13 and Downs syndrome. ${ }^{34,35}$ Associated congenital anomalies need to be ruled out in these cases. Diagnosis of a VID remnant can generally be made by the surgeon on physical examination if there are cutaneous or umbilical signs. Ultrasound, CT scan, Meckel's scan, and fistulogram may aid the diagnosis. ${ }^{36}$ All vitellointestinal duct remnants are surgically excised either by open or laparoscopic methods. It may simple wedge resection or bowel resection. Surgery is essential to prevent complications.

\section{LIMITATIONS OF THE STUDY}

This study is limited by lack of long term patient follow up.

\section{CONCLUSION}

VID remnants form an interesting group of congenital anomalies. Few cases present with clinical manifestations. There is a relatively higher incidence in the infantile age group along with male preponderance. The variable histology and presence of ectopic tissues make them very enticing. Histology of the VID remnants provides inroads into the embryogenesis of the vitelline duct, umbilicus and gastrointestinal tract. An awareness of the diversity of VID malformations and the possible presence of ectopic tissues on histology is essential for accurate diagnosis. Surgery is curative in most cases.

\section{REFERENCES}

1. Hegazy AA. Anatomy and embryology of umbilicus in newborns: a review and clinical correlations. Front Med. 2016;10 (3):271-277. https://doi.org/10.1007/s11684-016-0457-8

2. Abhyankar A and Lander AD. Umbilical disorders. Surg Oxf 2004;22:214217.

https://doi.org/10.1383/surg.22.9.214.50245

3. Hegazy AA. Clinical Embryology for Medical Students and Postgraduate Doctors. Berlin: Lap LambertAcademic Publishing, 2014

4. Kadian YS, Verma A, Rattan $\mathrm{KN}$ and Kajal P. Vitellointestinal Duct Anomalies in Infancy. J Neonatal Surg. 2016;5:30. https://doi.org/10.21699/jns.v5i3.351

5. Menezes M, Tareen F, Saeed A, Khan N and Puri P. Symptomatic Meckel's diverticulum in children: a 16-year review. Pediatr Surg Int. 2008; 24:575-577.

https://doi.org/10.1007/s00383-007-2094-4

6. Snyder CL. Meckel's diverticulum. In: Grosfeld JL, O'Neill JA,Fonkalsrud EW, Coran AG (eds). Pediatric Surgery. MosbyElsevier, Philadelphia, PA, 2006; 1304-12. https://doi.org/10.1016/B978-0-323-02842-4.50085-1

7. DiSantis DJ, Siegel MJ and Katz ME. Simplified approach to umbilical remnant abnormalities. Radiographics. 1991;11(1):59-66. https://doi.org/10.1148/radiographics.11.1.1996398

8. Bagade $\mathrm{S}$ and Khanna $\mathrm{G}$. Imaging of omphalomesenteric duct remnants and related pathologies in children. Curr Probl Diagn Radiol. 2015;44(3):246-255.

https://doi.org/10.1067/j.cpradiol.2014.12.003

9. Sadler TW. Langman's Medical Embryology. $13^{\text {th }}$ ed. Baltimore: Lippincott Williams \& Wilkins, a Wolters Kluwer; 2015.

10. Snyder CL. Current management of umbilical abnormalities andrelated anomalies. Semin Pediatr Surg. 2007;16(1):41-49 https://doi.org/10.1053/j.sempedsurg.2006.10.006

11. Durakbasa CU, Okur $\mathrm{H}$ and Mutus HM. Symptomatic omphalomesenteric duct remnants in children. Pediatrics 
International. 2010; 52 (3): 480-484.

https://doi.org/10.1111/j.1442-200X.2009.02980.x

12. Celebi S, Ozaydin S, Polat E, Basdas C, Alim ER and Sander S Vitelline duct pathologies in neonates. North Clin Istanb. 2018;5(3):211-215

13. Ueberrueck $T$, Meyer $L$ and Koch A, Hinkel M, Kube $R$ and Gastinger I. The significance of Meckel's diverticulum in appendicitis-A retrospectiveanalysisof233cases. World J Surg. 2005;29 (4 ):455-458.

14. Gupta AK, Chaturvedi V and Tuteja N. Demography of the remnant of omphalomesenteric duct. Formos J Surg 2019; 52:201-206

https://doi.org/10.4103/fjs.fjs 1219

15. Solomon-Cohen E, Lapidoth M, Snast I, Ben-Amitai D and Zidan O. Cutaneous presentations of omphalomesenteric duct remnant: A systematic review of the literature. J Am Acad Dermatol. 2019;81(5):1120-1126.

https://doi.org/10.1016/j.jaad.2019.02.033

16. Hatipoglu S, Abdullayev R, Benlioglu C, Goksu M, Hqatipoglu F and Bayramoglu E. Enterocutaneous Fistula formation of meckel's diverticulum via the urachal cyst in an adult patient. A case report and literature review. Int J Case Rep Med. 2014;1-9. https://doi.org/10.5171/2014.419399

17. Lee NK, Kim S and Jeon TY. Complications of congenital and developmental abnormalities of the gastrointestinal tract in adolescents and adults: Evaluation with multimodality imaging. Radiographics. 2010;30(6):1489-1507. https://doi.org/10.1148/rg.306105504

18. Bender E and Schmidt SP. Extraintestinal heterotopic gastric tissue stimulating acute appendicitis. World J. Gastroenterol. 2008; 14:2268-2269.

https://doi.org/10.3748/wjg.14.2268

19. Singaravel $\mathrm{S}$ and Yadav PC. Histomorphology of the lesions of the umbilicus: Are we naïve about the navel? Indian J Pathol Microbiol. 2021;64(1):91-95.

https://doi.org/10.4103/IJPM.IJPM_307_20

20. Artigas V, Calabuig R, Badia F, Rius X, Allende $L$ and Jover J. Meckel's diverticulum: Value of ectopic tissue. Am J Surg. 1986; 151:631-634.

21. Ezejiofor IF, Ugwu JO, Ndukwe CO, Madubuike KC and Ozor NS. Umbilical polyp; an anomaly of omphalomesenteric duct remnant from birth in a 3-year-old male child: A case report and review of literature. Med J DY Patil Vidyapeeth. 2018; 11:175-177.

22. Al Habeeb A and Ghazarian D. Umbilical mucosal polyp. J Clin Pathol. 2010;63:282. https://doi.org/10.1136/jcp.2009.070904

23. Park E, Kim H, Jung KW and Chung JH. Heterotopic pancreas in omphalomesenteric duct remnant results in persistent umbilical discharge. Korean J Pathol. 2014;48(4):323-326.

https://doi.org/10.4132/KoreanJPathol.2014.48.4.323
24. Zhao Z, Sim CK and Mantoo S. Heterotopic pancreas in the omphalomesenteric duct remnant in a 9-month-old girl: a case report and literature review. Diagn Pathol. 2017;12(1):49.

https://doi.org/10.1186/s13000-017-0643-2

25. Chandan VS and Wang W. Pancreatic heterotopia in the gastric antrum. Arch Pathol Lab Med. 2004; 128: 111-112. https://doi. org/10.5858/2004-128-111-PHITGA

26. Gupta MK, Karlitz JJ, Raines DL, Florman SS and Lopez FA. Clinical case of the month. Heterotopic pancreas. J La State Med Soc. 2010;162: 310-313.

27. Baysoy G, Balamtekin N, Uslu N, Karavelioğlu A, Talim B and Ozen H. Double heterotopic pancreas and Meckel's diverticulum in a child: do they have a common origin? Turk J Pediatr. 2010; 52: 336-338.

28. Matsagas MI, Fatouros M, Koulouras B and Giannoukas AD. Incidence, complications, and management of Meckel's diverticulum. Arch Surg. 1995;130:143-146. https://doi.org/10.1001/archsurg.1995.01430020033003

29. Willis RA. Some unusual developmental heterotopias. Br Med J. 1968; 3:267-272.

30. Tamilselvan K, Mohan A, Cheslyn-Curtis S and Eisenhut M. Persistent umbilical discharge from an omphalomesenteric duct cyst containing gastric mucosa. Case Rep Pediatr. 2012;482185. https://doi.org/10.1155/2012/482185

31. Sharma S, Maheshwari $U$ and Bansal N. Ectopic Pancreatic, Gastric, And Small Intestine Tissue In An umbilical Polyp, Causing Persistent Umbilical Discharge In A 2 Year Old Child - A Rare Case Report Journal of Evolution of Medical and Dental Sciences.2013;5(2):447-451. https://doi.org/10.14260/jemds/286

32. Cullen JJ, Kelly KA, Moir CR, Hodge DO, Zinsmeister AR and Melton LJ. Surgical management of Meckel's diverticulum. An epidemiologic, population-based study. Ann Surg. 1994;220: 564-568. https://doi.org/10.1097/00000658-199410000-00014

33. Zafer Y, YigitS, Turker A and Tekin G. Patent Omphalomesenteric Duct. Turk J Med Sci. 2000; 30:83-85.

34. Elabute EA and Ransome-Kuti O. Patent vitellointestinal duct with ilealprolapse. Arch Surg. 1965;91:456-460. https://doi.org/10.1001/archsurg.1965.01320150086013

35. Blair SP and Beasley SW. Intussusception vitello-intestinal tract through and exomphalos in trisomy 13. Pediatr Surg Int. 1997; 4:422-423 https://doi.org/10.1007/BF00169706

36. Iwasaki M, Taira K, Kobayashi H and Saiga T. Umbilical cyst containing ectopic gastric mucosa originating from an Omphalomesenteric duct remnant. J Pediatr Surg. 2009;44:2399-2401

https://doi.org/10.1016/j.jpedsurg.2009.08.027

\section{Authors Contribution:}

OHRK - Concept and design of the study, analysis and interpretation of data, drafting of the article, literary review, revision and preparation of manuscript;

SS - Acquisition of data, analysis and interpretation of data, literary review, preparation of manuscript, revision and final approval; VPGJ - Concept and design of the study, intellectual content; RRK - Concept, intellectual content, preparation of manuscript and revision.

Work attributed to:

Niloufer Hospital, Osmania Medical College, Hyderabad, Telangana, India.

Orcid ID:

Dr Othuluru Hema Radhika Krishna - (D) https://orcid.org/0000-0001-6796-0143

Dr Srinivas Srirampur - (1) https://orcid.org/0000-0003-1581-9679

Dr Gaddam Janardhan Vani Padmaja - (1) https://orcid.org/0000-0002-6072-1382

Dr Ramesh Reddy Kota - (D) https://orcid.org/0000-0002-2017-7546

Source of Support: Nil, Conflict of Interest: None declared. 